\title{
First comprehensive report of bacteria spp. associated with cloaca of Laudakia nupta (Sauria: Agamidae) in Iran using molecular studies
}

\author{
Farkhondeh Sayyadi, Nasrullah Rastegar-Pouyani", Mehri Azadbakht and Khosrow Chehri
}

\begin{abstract}
Iran bears a remarkable variety of reptiles. One of the lizard families occurring in Iran is the Family Agamidae which is widely are distributed throughout the old world. The large-scaled rock agamid, Laudakia nupta, is one of the well-known agamid. There are few reports of cloacal microbial on reptiles hence their function in cloacae remains unknown. Laudakia nupta usually live in rural and urban areas and close vicinity to man, they are likely to play an important role in the spread of disease that may be caused by these microorganisms and their transmission to man. Therefore, the aim of this study was to identify the bacterial flora colonizing the cloacal region of Laudakia nupta using molecular studies. The cloacal fluids were directly placed on nutrient agar (NA) plates and incubated at $25 \pm 2{ }^{\circ} \mathrm{C}$ for $48 \mathrm{~h}$. The resulting bacterial colonies were transferred to fresh nutrient agar (NA) plates for molecular studies. Twelve isolates were obtained from 17 specimens of Laudakia nupta. All bacteria isolates were identified as Bacillus subtillis (5), Bacillus cereus (4), Bacillus sp. (1), Pseudomonas putida (1), and Pseudomonas sp. (1) based on partial sequences of the $16 \mathrm{~s} r R N A$ gene. This is the first comprehensive report of bacteria spp. associated with cloaca of Laudakia nupta using molecular studies. In this research, we found that Laudakia nupta can be a carrier of bacteria which can transfer microorganisms to hosts.
\end{abstract}

Keywords: Bacillus, Pseudomonas, Cloaca, Lizard, Bacteria, Laudakia nupta

\section{Introduction}

Reptiles are cold-blooded vertebrates among the oldest amniotes and are highly diverse in their morphology and ecological niches [1]. The Agamidae, a monophyletic family of lizards, are distributed throughout the old world [2]. In Iran, the family Agamidae encompass at least four genera: Laudakia, Calotes, Trapelus and Phrynocephalus $[3,4]$. The large- scaled rock lizard is commonly referred to as Laudakia nupta. They are abundant on and among large rocks having deep crevices and around human habitation, commonly seen on walls, mud-brick dwellings, and the tombs and monuments of graveyards [3-6]. Reptiles have usually microbial contamination and asymptomatic carriers to transmission of microorganisms [7]. Reptiles, even if appear healthy, often able to carry a wide variety of

\footnotetext{
* Correspondence: nasrullah.r@gmail.com

Department of Biology, Faculty of Basic Sciences, Razi University, Taq-e Bostan, Bagh-e Abrasham, Kermanshah 6714967346, Iran
}

pathogens that can infect humans [8,9]. Viral, protozoal, fungal and parasitic agents can infect the cold-blooded animals, but bacteria are the most common pathogens recovered from these animals and in most cases they can be transmitted to humans [9]. Some bacteria are cause of infectious pathologies in reptiles, but often represent the normal bacterial flora of these animals [9]. Also different species of lizards have also been associated various bacteria species for example, there are a number of bacteria in the cloaca of giant lizards, including Citrobacter spp., Enterobacter spp., Escherichia coli, Klebsiella oxytoca, Salmonella spp., P. aeruginosa, Corynebacterium spp., Staphylococcus spp., and Streptococcus spp. [10]. The main bacterial infections, transmitted from reptiles to humans are salmonellosis, mycobacteriosis, chlamydophilosis, Aeromonas and Pseudomonas infections [9]. Pseudomonas is Gram negative microorganisms widely spread in the environment and considered opportunistic

(c) The Author(s). 2019 Open Access This article is distributed under the terms of the Creative Commons Attribution 4.0 International License (http://creativecommons.org/licenses/by/4.0/), which permits unrestricted use, distribution, and reproduction in any medium, provided you give appropriate credit to the original author(s) and the source, provide a link to the Creative Commons license, and indicate if changes were made. The Creative Commons Public Domain Dedication waiver (http://creativecommons.org/publicdomain/zero/1.0/) applies to the data made available in this article, unless otherwise stated. 
pathogens for animals and humans [9]. P. spp. usually cause infections of gastrointestinal tract in human and animal [11-13]. Bacillus is Gram-positive, aerobic, ubiquitous bacteria that live in every natural environment [11-14]. Humans may come in contact with $B$. spp. that may cause illness in them [9]. B. cereus can result in intoxications that cause nausea, vomiting, and abdominal cramps or diarrhea [11-13].

L. nupta are plentiful in rural and urban areas and live in close vicinity to man, they are likely to play an important role in the spread of disease that may be caused by these bacteria and transmission to man. Therefore, identification the bacterial flora associated with cloaca of L. nupta is important. The aims of this study were to characterize bacterial flora cloacal sites in rock lizard agama. This study has helped us to understand the normal bacterial flora in L. nupta.

\section{Results}

Our objective was to demonstrate the bacteria present in the cloacal fluid of Laudakia nupta that observed under the stereo microscope. Twelve isolates of aerobic bacteria were obtained from cloacae. All isolates were chosen for DNA sequence analysis using the $16 s r R N A$ gene. After molecular studies, DNA extraction and PCR reaction, all bacteria isolates were identified as B. subtillis (5), B. cereus (4), Bacillus sp. (1), P. putida (1), and Pseudomonas sp. (1). Then obtained sequences were compared with those on the NCBI. From similarities searched at NCBI database, identification of all species was confirmed with statistical significance.

\section{Discussion}

The results of this investigation demonstrate the aerobic bacterial flora in the cloacae of rock lizard agama, $L$. nupta. During recent years some reptiles including turtles, snakes and lizards are kept in domestic environment and often bred in houses [9]. L. nupta usually lives in rural and urban areas and in the vicinity of humans [15]. Reptiles although clinically healthy, often carry and transmit opportunistic pathogens such as bacteria which can become cause of serious infections [9]. The bacterial species including Stenotrophomonas maltophilia, Pseudomonas spp., Citrobacter spp., Enterobacter spp., Escherichia coli, Proteus spp., Serratia spp., and Salmonella spp. isolated from healthy captive green iguanas that can be a potential health risk for humans [8-19]. Our results showed that B. subtillis, B. cereus, Bacillus sp., P. putida, and Pseudomonas sp. occurred in the cloaca of L. nupta. Pseudomonas spp. is widespread in the environment and considered opportunistic pathogens for animals and humans [9]. Pseudomonas spp., Citro bacterspp., Proteus vulgaris, Enterobacter spp., Serratia spp., and Salmonella spp.are capable of causing opportunistic infection in reptiles [8-22]. Pseudomonas spp. cause infections of urinary tract, respiratory system, skin, soft tissue, bone, joint and gastrointestinal tract [9-23]. P. putida, and Pseudomonas sp. were present in our study and are thus a potential risk.

Bacillus sp. has been introduced as the cloacal bacterial flora of the snake Elaphe quatuorlineata, [24]. Most of the isolated bacteria such as Bacillus sp. have already been described as causes of infection in both reptiles and humans. B.cereus was also identified as opportunistic pathogen of humans [25]. In our study B. subtillis B. cereus and Bacillus sp., were part of the natural cloacal flora of the agamid, L. nupta. Humans may come in contact with Pseudomonas and Bacillus bacteria from the environment and directly from spreader animals [9-23]. Therefore, reptiles can serve as the carriers for the transmission of microorganisms such as bacteria to other animals and humans.

In reptiles, the microbial flora may not be pathogenic for their natural hosts but it could be dangerous and pathogenic if they get contact with humans particularly elderly, pregnant women, those with a weaken the immune system, and other animals [9]. In fact, it can be claimed that most infections and contamination of reptiles are due to pathogenic bacteria and since $L$. nupta live in close vicinity to man, they are likely to play an important role in the spread of various diseases. Therefore, identification of the normal bacterial flora associated with cloaca of $L$. nupta is important.

\section{Conclusions}

In conclusion, the results of this study indicate that rock lizard L. nupta harbor some bacteria in cloacal region. Many isolated bacteria have already been described as causes of infection. To the author $\mathrm{s}$ knowledge this is the first survey of bacterial flora colonizing the cloacal region of rock lizard. By doing this research, we found that L. nupta can be a carrier of microorganisms which can transfer bacteria to the environment, other animals, and humans. This study only introduce and identification of bacteria associated with cloacal region of the rock lizard L.nupta and it is recommended that the pathogenesis tests be performed on bacterial flora in this region.

\section{Materials and methods}

This research was approved by the ethics committee (95.01.20) of Razi University for 17 specimens of L. nupt.

\section{Isolation of bacterial species}

From May to September 2017, 17 specimens of L.nupta (male and female) collected from Kermanshah Province, Western Iran (Fig.1a). The lizards were taken from the mountainous areas, among rocks and crevices and ruins. The collected lizards were identified based on key identification. The animals were transferred to the laboratory. Also in the laboratory, sufficient light, optimum temperature, water and food were provided for samples. During the survey of 

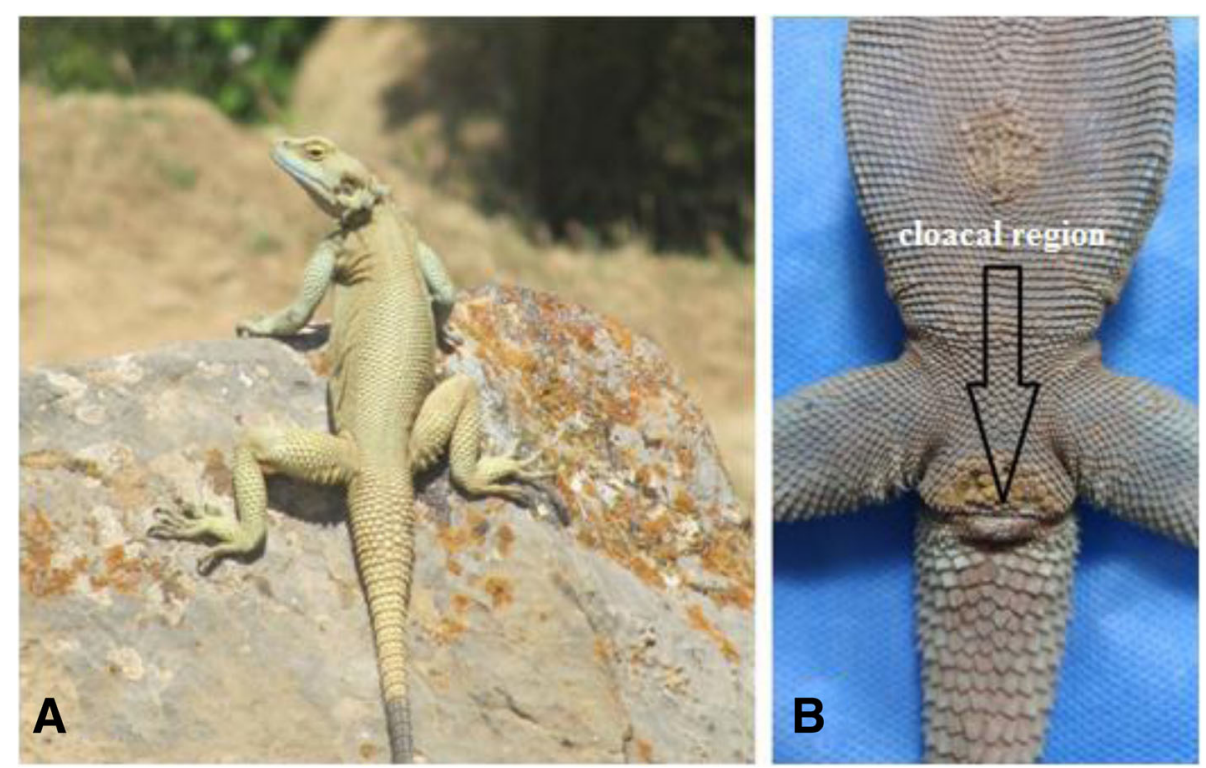

Fig. 1 a Laudakia nupta in natural habitat. b Cloacal area in Laudakia nupta.l: Cloacal region

cloacal region of $L$. nupta, we noticed the presence of microorganisms such as bacteria in this region under the stereo microscope (Fig.1b). The exit part of cloacal region of samples was disinfected by ethylic alcohol (70\%). The cloacal fluid from inside of cloacal region were directly placed on nutrient agar (NA) plates and incubated at $25 \pm 2{ }^{\circ} \mathrm{C}$ for $48 \mathrm{~h}$. The resulting bacterial colonies were transferred to fresh nutrient agar (NA) plates for further studies.

DNA extraction, PCR amplification, and sequencing alignment The DNA extraction was done by alkaline lysis method [16]. The DNA amplification of the $16 s$ rRNA gene was conducted using two universal primers 27F (5-AGAG TTTGGATCMTGGCTCAG-3) and 1429 (5-CGGT TACCTTGTTACGACTT-3) [17]. $50 \mu \mathrm{l}$ of PCR product was sent to company Bioneer (Korea) for sequencing. The PCR mixture was centrifuged for $30 \mathrm{~s}$ and tubes were transferred to the Thermal Cycler Apparatus. The reaction of PCR was prepared in the total volume of $50 \mu \mathrm{l}$ in the eppendorf tubes. Nucleotide sequences were manually edited and assembled with BioEdit software version 5.0 (bioedit.software.informer.com). The aligned sequences were BLAST in genome database of GenBank to identify all the selected isolates. The edited $16 \mathrm{~s} r \mathrm{rNA}$ gene sequences were compared with other available bacterial species sequences in the GenBank [18].

\section{Abbreviations}

B: Bacillus; L.nupta: Laudakia nupta; P: Pseudomonas

\section{Acknowledgements}

We thank Hamidreza Azhar, Morteza Azizi and Ali Faramarzi for their help in collecting Laudakia nupta specimens.

\section{Funding}

This research did not receive any specific grant from funding agencies in the public, commercial, or not-for-profit sectors.

Availability of data and materials Not applicable.

\section{Authors' contributions}

Theses authors equally contributed to this study. All authors read and approved the final manuscript.

\section{Authors' information}

Farkhondeh Sayyadi: Ph.D. student of biology in Razi University of Kermanshah, Iran.

Nasrullah Rastegar-Pouyani: Professor of Zoology in Razi University of Kermanshah, Iran.

Mehri Azadbakht: Assistant Professor of Anatomy in Razi University of Kermanshah, Iran.

Khosrow Chehri: Associate Professor of Pharmacology in Razi University of Kermanshah, Iran.

\section{Competing interests}

The authors declare that they have no competing interests.

Received: 21 March 2019 Accepted: 29 April 2019

Published online: 24 June 2019

\section{References}

1. Van Hoek ML. Antimicrobial Peptides in Reptiles. Pharmaceuticals. 2014;7: 723-53. https://doi.org/10.3390/ph7060723.

2. Honda M, Ota H, Kobayashi M, Nabhitanhata J, Yong H-S, Sengoku S, Hikida T. Phylogenetic relationships of the family Agamidae (Reptilia: Iguania) inferred from mitochondrial DNA sequences. ZoolSci. 2000;17:527-37.

3. Anderson SC. The Lizards of Iran, Contributions to Herpetology, vol. 15. Saint Louis: Society for the Study of Amphibians and Reptiles, New York; 1999. p. 1-442.

4. Rastegar-Pouyani N, Johari SM, Rastegar-Pouyani E. Field guide to the reptiles of Iran, vol. 1. 2nd ed. Kermanshah: Lizards Razi University Publishing; 2008.

5. Rastegar- Pouyani N, Nilson G. Taxonomy and biogeography of the Iranian species of Laudakia (Sauria: Agamidae). Zool Middle East. 2002;26(1):123-8. https://doi.org/10.1080/09397140.2002.10637926. 
6. Rastegar- Pouyani N, Johari M, Parsa H. Reptiles of Iran, Volume 1 Lizard. Kermanshah: Razi University Press; 2006. p. 139. In Persian

7. Ippen R, Zwart P. Infectious and parasitic diseases of captive reptiles and amphibians, with special emphasis on husbandry practices which prevent or promote diseases. Rev. sci. tech. 1996;15(1):43-54 Off. int. Epiz.

8. Romero SB, Čižžk A, Masaříková M, Knotek Z. Choanal and cloacal aerobic bacterial flora in captive green iguanas: a comparative analysis. Acta vet Brno. 2015;84:19-24. https://doi.org/10.2754/avb201584010019.

9. Ebani W, Fratini F. Bacterial zoonoses among domestic reptiles. Annali Fac Med Vet. 2005;58:85-91.

10. Martínez Silvestre A, Silveira L, Mateo JA, Urioste J, Rodríguez Domínguez MA, Pether J. Cloacal microbiology in threatened captive giant lizards from the Canary Islands (genus Gallotia). Rev EspHerp. 2003;17:29-37.

11. Gilbert RJ. Bacillus cereus. In: Riemann H, Bryan FL, editors. Food-borne Infections and Intoxications. 2nd ed. New York: Academic Press; 1979. p. $495-514$

12. Griffiths MW, Schraft H. Bacillus cereus food poisoning. In: Cliver DO, Riemann HP, editors. Food borne Diseases. 2nd ed. New York: Academic Press; 2002. p. 261-70.

13. Schraft $H$, Griffiths MW. Bacillus cereus gastroenteritis. In: Riemann $H$, Cliver DO, editors. Foodborne Infections and Intoxications. 3rd ed. New York: Academic Press; 2006. p. 561-82.

14. Peter CB. Turnbull. Bacillus. In: Medical microbiology, 4nd ed, University of Texas Medical Branch at Galveston, 1996.

15. Enweani IB, Uwajeh JC, Bello CSS, Ndip RN. Fungal carriage in lizards. Mycoses. 1997:40:115-7.

16. Rademaker JL, de Bruijn FJ. Characterization and classification of microbes by rep-PCR genomic fingerprinting and computer assisted pattern analysis. DNA markers: protocols, applications and overviews, vol. 1; 1997. p. 151-71.

17. Jiang H, Dong H, Zhang G, Yu B, Chapman LR, Fields MW. Microbial diversity in water and sediment of Lake Chaka, an athalassohaline lake in northwestern China. App Environ Microbiol. 2006;72:3832-45.

18. Lin M, Al-Holy M, Al-Qadiri H, Chang S, Kang DH, Rodgers BD, Rasco BA. Phylogenetic and spectroscopic analysis of Alicyclobacillus isolates by $16 \mathrm{~S}$ rRNA sequencing and mid-infrared spectroscopy. Sens \& Instrumen Food Qual. 2007;(1):11. https://doi.org/10.1007/s11694-006-9000y.

19. Johnson-Delaney CA. Reptile zoonoses and threats to public health. In: Mader DR, editor. Reptile medicine and surgery. 2nd ed. St. Louis: SaundersElsevier Publishing; 2006. p. 1017-30.

20. Mader DR. Common bacterial disease and antibiotic therapy in reptiles. Antimicrob Ther in Exot, Supplement to Comp Cont Educ Pract. 1998;20:23-33.

21. Harris NB, Rogers DG. Septicemia associated with Stenotrophomonasmaltophiliain a west African dwarf crocodile (Osteolaemustetraspissubsp. tetraspis). J Vet Diagn Investig. 2001;13:255-8.

22. Mehler SJ, Bennett RA. Oral, dental and beak disorders of reptiles. Vet ClinExotAnim. 2003;6:477-503.

23. Manno G, Dalmstri C, Tabacchini S, Vandamme P, Lorini R, Minicucci L, Romano L, Giannattasio A, Chiarini L, Bevivino A. Epidemiology and clinical course of Burkholderia cepacia complex infections, particularly those caused by different Burkholderia cenocepacia strains, among patients attending an italian cystic fibrosis center. J Clin Microbiology. 2004;42:1491-7.

24. Lukač M, Tomić DH, Mandac Z, Mihoković S, Prukner-Radovčić E. Oral and cloacal aerobic bacterial and fungal flora of free-living four-lined snakes (Elaphequatuorlineata) from Croatia. Vet arhiv. 2017;87(3):351-61.

25. ICMSF, International Commission on microbiological Specifications of foods. Bacillus cereus. In: Roberts TA, Baird-Parker AC, Tompkin RB, editors. Microorganisms in food 5 microbiological specifications of food pathogens. London: Blackie Academic and Professional; 1996. p. 20-35.

\section{Publisher's Note}

Springer Nature remains neutral with regard to jurisdictional claims in published maps and institutional affiliations.

Ready to submit your research? Choose BMC and benefit from:

- fast, convenient online submission

- thorough peer review by experienced researchers in your field

- rapid publication on acceptance

- support for research data, including large and complex data types

- gold Open Access which fosters wider collaboration and increased citations

- maximum visibility for your research: over $100 \mathrm{M}$ website views per year

At $\mathrm{BMC}$, research is always in progress.

Learn more biomedcentral.com/submissions 